BENJAMIN SUTER

\title{
REGULATION OF DISTANCE SELLING METHODS
}

\author{
LLM RESEARCH PAPER \\ LAWS 532: CONSUMER LAW
}

FACULTY OF LAW

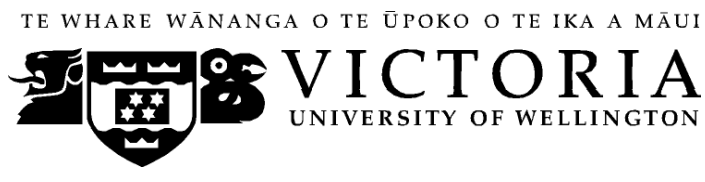

2014 


\section{Contents}

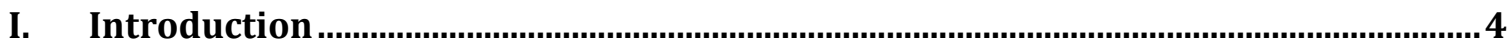

II. Regulation of distance selling in New Zealand .............................................................

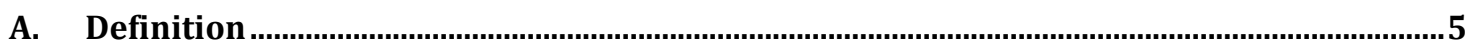

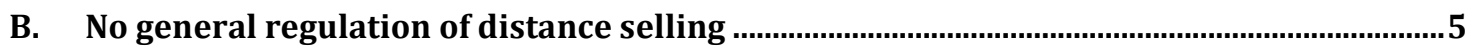

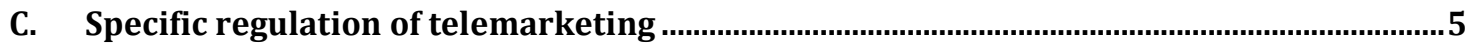

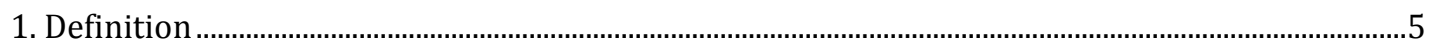

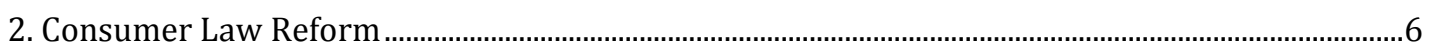

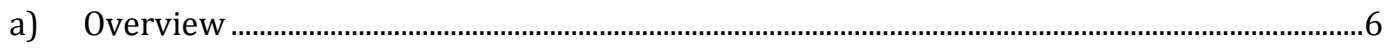

b) Same regulation of uninvited telemarketing and door-to-door sales?..................................... 7

c) What constitutes an invitation for telemarketing? ......................................................................

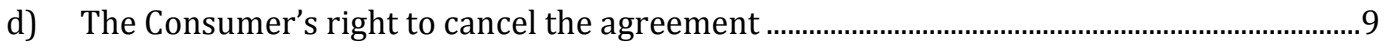

e) Disclosure requirements relating to the agreement................................................................... 10

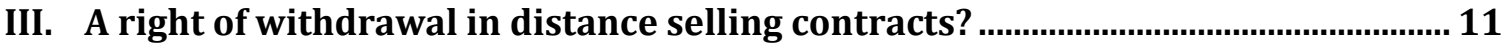

A. The right of withdrawal pursuant to the Directive on consumer rights ..........................11

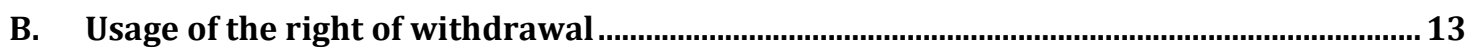

C. Analysis of the right of withdrawal from an economic perspective .................................13

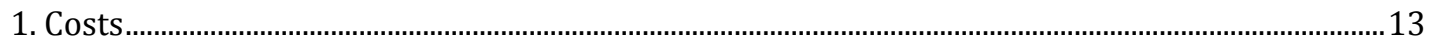

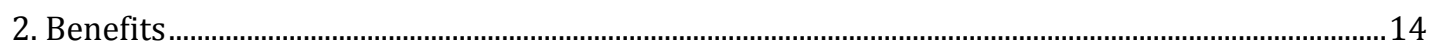

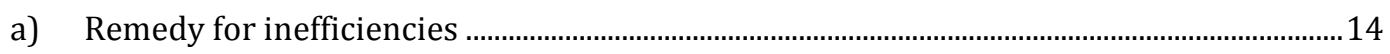

b) Allocation of costs and benefits ...............................................................................................14

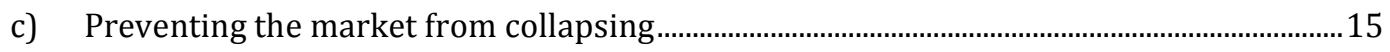

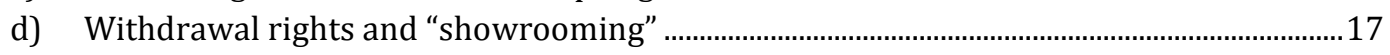

D. Analysis of the right of withdrawal from a behavioural psychology perspective ...........19

1. Grounds for withdrawal rights ......................................................................................................19

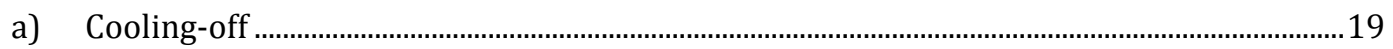

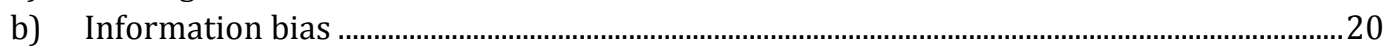

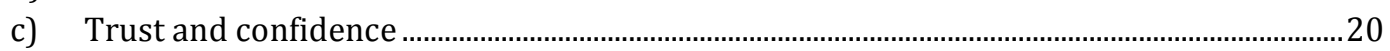

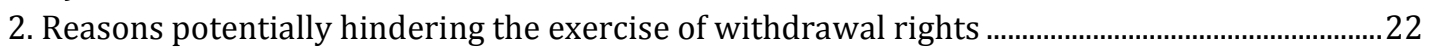

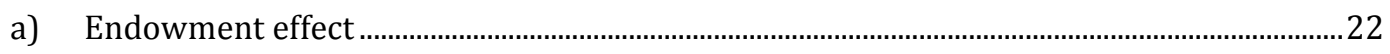

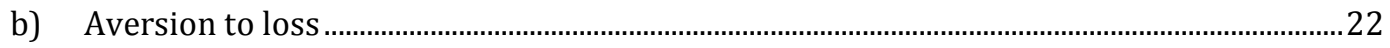

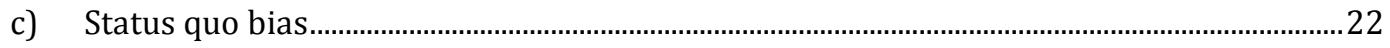

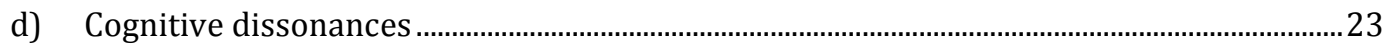

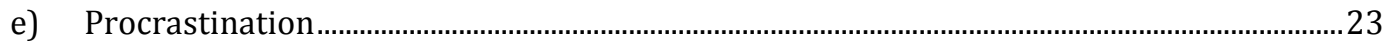

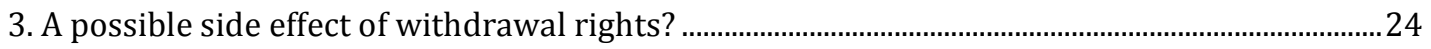

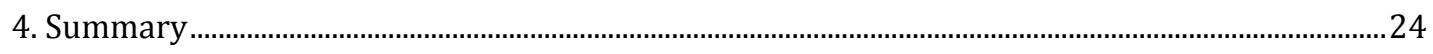

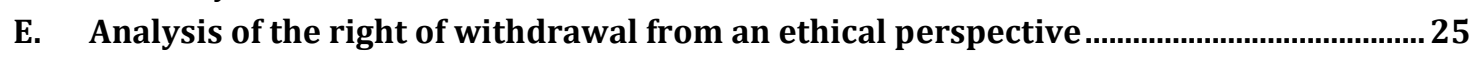

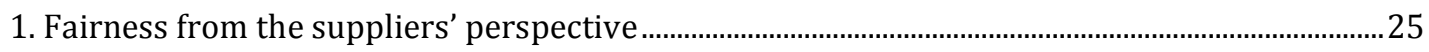

a) A general right of withdrawal in distance selling contracts................................................25

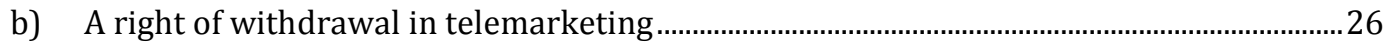

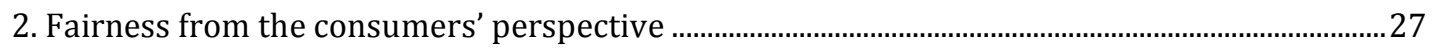

a) A general right of withdrawal in distance selling contracts..................................................27

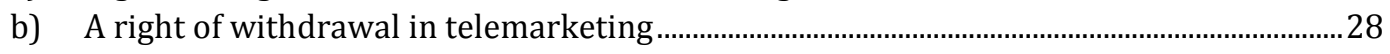

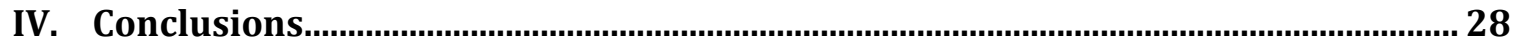




\section{Abstract}

This paper examines New Zealand's distance selling regulation, in particular the changes made in the course of the recent consumer law reform. First, the paper assesses the reforms with regard to telemarketing. While some criticism is expressed as to the content of the prescribed disclosure by the supplier, the approach followed is approved of in general. The paper then examines the merits of a general right of withdrawal in distance selling contracts as it exists in the European Union. Analysing withdrawal rights from an economical, psychological and ethical perspective, the paper argues that both from a supplier's and from a consumer's point of view, the advantages are outweighed by the disadvantages that come with withdrawal rights.

\section{Word length}

The text of this paper (excluding abstract, table of contents, footnotes and bibliography) comprises 7,462 words.

\section{Subjects and Topics}

\section{Telemarketing}

Distance selling contracts Rights of withdrawal. 


\section{Introduction}

Distance selling is nothing new. It is thought that Aaron Montgomery Ward, a nineteenth century American entrepreneur based in Chicago, was the first salesman to offer distance selling to consumers when he published the world's first general merchandise mail-order catalogue in $1872 .^{1}$

However, distance selling methods changed over time as new technologies developed, and new methods have made distance selling increasingly popular in the last decades. Today, more traditional distance selling methods such as mail order sales and telemarketing have been overtaken by internet-based distance sales.

The main issue that all these methods have in common is that consumers are not dealing face-to-face with the supplier and cannot examine the good they are about to purchase.

The increasing popularity of distance selling has led various jurisdictions, namely the European Union, to regulate it in depth and provide consumers with certain rights to protect them from perceived dangers associated with it. In particular, the European Union has as early as in 1997 granted consumers a general right to withdraw from distance selling contracts after receiving (and inspecting) the goods.

New Zealand's recent consumer law reform did regulate some aspects of distance selling and in particular one method of distance selling: telemarketing. However, the law reform did not include a general regulation of distance selling, let alone the introduction of a general right of withdrawal in distance selling contracts.

This paper will try to assess whether this is an adequate solution to consumer protection in these types of sale. In doing so, this paper will begin by examining the New Zealand legislation on telemarketing. Then, it will assess withdrawal rights as established in the European Union first from an economic and then from a behavioural psychology perspective before finally examining if they are justified from an ethical point of view.

\footnotetext{
1 "Aaron Montgomery Ward (1843-1913)" Forbes.com < www.forbes.com/2005/07/08/montgomery-wardsears-debt-cx_0708ward.html>; Wikipedia, the free encyclopedia (2014) Aaron Montgomery Ward $<$ http://en.wikipedia.org/w/index.php?title=Aaron_Montgomery_Ward\&oldid=613392551>.
} 


\section{Regulation of distance selling in New Zealand}

\section{A. Definition}

A distance selling contract can be defined as any contract concerning the sale of goods or services between a supplier and a consumer exclusively using means of distance communication (such as telephone, internet or mail) until the contract is concluded. ${ }^{2}$

\section{B. No general regulation of distance selling}

One characteristic that all distance selling methods have in common is that the goods can not be handed over at the time the contract is concluded. Instead, they have to be delivered to the consumer. Thus, while delivery of goods regulations do not apply to distance selling contracts only, they do apply to all distance selling contracts. Such a regulation is found in s $5 \mathrm{~A}$ of the Consumer Guarantees Act 1993, which provides a statutory guarantee that the consumer will receive the goods, absent a respective agreement, within a reasonable time.

Otherwise, no regulation specifically drafted to cover all distance selling methods can be found. However, New Zealand recently regulated one specific method of distance selling: telemarketing.

\section{Specific regulation of telemarketing}

\section{Definition}

Wikipedia defines telemarketing as "a method of direct marketing in which a salesperson solicits prospective customers to buy products or services," either by phone or in a subsequent conversation via comparable media. ${ }^{3}$ Thus, telemarketing is by definition a distance selling method where the phone is used. In other words, telemarketing is the distance selling variant of direct selling.

\footnotetext{
${ }^{2}$ See Directive 2011/83/EU on consumer rights [2011] OJ L304/64 2011 (European Union), art 2(7).

3 Wikipedia, the free encyclopedia (2014) Telemarketing <http://en.wikipedia.org/w/index.php?title= Telemarketing\&oldid $=617088640>$.
} 


\section{Consumer Law Reform}

\section{a) Overview}

The Ministry of Consumer Affairs noted in its additional paper on the regulation of uninvited direct selling that direct selling techniques and strategies take "psychological advantage of the selling environment (usually the consumer's home, workplace or other environment where the consumer cannot easily walk away without buying something first) to pressure the consumer". ${ }^{4}$ Additionally, consumers are "likely to feel vulnerable because they are unprepared for the sale and a stranger is in their house or workplace uninvited." ${ }^{5}$ These characteristics make consumers prone to poor purchasing decisions. ${ }^{6}$

In terms of New Zealand regulation, two forms of telemarketing must be distinguished, depending on whether the consumer initiated the negotiations or not. If the latter is the case ("cold calls"), then the telemarketing is called "uninvited direct sale agreement" and becomes the subject matter of a specific regulation.

"Uninvited direct sale agreements" are accordingly agreements

- for the supply, in trade, of goods or services to a consumer; ${ }^{7}$

- $\quad$ as a result of negotiations by telephone; ${ }^{8}$

- where the consumer has not invited the supplier to make a telephone call; ${ }^{9}$ and

- where the price paid or payable by the consumer either is more than NZD 100 or cannot be ascertained at the time of supply. ${ }^{10}$

Uninvited telemarketing that satisfies all these conditions is treated the same way as door-to-door sales. ${ }^{11}$ This has two major consequences, which are set out in more detail

\footnotetext{
${ }^{4}$ Ministry of Consumer Affairs Consumer Law Reform Additional Paper: Regulation of Uninvited Direct Selling (2010) at 1.

${ }^{5}$ At 1.

${ }^{6}$ At 1.

${ }^{7}$ Fair Trading Act 1986, s 36K(1).

${ }^{8}$ Fair Trading Act, ss 36K(1)(a), 36K(3).

${ }^{9}$ Fair Trading Act, s 36K(5).

${ }^{10}$ Fair Trading Act, s 36K(1)(b).

${ }^{11}$ See Fair Trading Act, s 36K(2)-(3).
} 
below: First, the supplier must meet a number of disclosure requirements; ${ }^{12}$ and second, the consumer may cancel the agreement within five working days after receiving a copy of the agreement. ${ }^{13}$

\section{b) Same regulation of uninvited telemarketing and door-to-door sales?}

It is not self-evident that uninvited telemarketing and door-to-door sales should be treated the same. This traces back to an obiter dictum by the Court of Appeal in Commerce Commission $v$ Telecom Mobile Ltd. ${ }^{14}$ In this case, the Court first noted that the application of the Door to Door Sales Act was triggered if the agreement was made somewhere "other than appropriate trade premises". ${ }^{15}$ The Court then noted that in the case at hand cold calls were made from a call centre, which could be argued to be "appropriate trade premises". ${ }^{16}$ The Court however was not persuaded that the place where the calls were made from should decide on whether the Act applied. ${ }^{17}$ The Court held: ${ }^{18}$

In that general context, there may be something to be said for the view that sales effected by a telemarketing campaign involving the cold calling of prospects at their homes and completed, from the point of view of such prospects at their homes, should be regarded as having been made otherwise than at "appropriate trade premises" even if the telemarketer happens to be ringing from a shop.

Having regard to the reasons given by the Ministry of Consumer Affairs in its additional paper on the regulation of uninvited direct selling ${ }^{19}$ though it appears that consumers are less likely to feel vulnerable when talking to a salesperson on the phone than when being confronted with a stranger in their house or workplace. ${ }^{20}$ Against this

\footnotetext{
${ }^{12}$ See below II.C.2.d).

${ }^{13}$ Fair Trading Act, s 36M.

${ }^{14}$ Commerce Commission v Telecom Mobile Ltd NZCA 218, [2006] 1 NZLR 190 (NZCA).

${ }^{15}$ At [15].

${ }^{16}$ At [20].

${ }^{17}$ At [40]-[43].

${ }^{18}$ At [44]; this statement was criticised by Kate Tokeley "Telemarketing and the Door to Door Sales Act 1967" (2006) 37 VUWLR 609 at 617-620 (arguing that the Act's applicability was, pursuant to its unambiguous wording, depending on whether the a contract was concluded at appropriate trade premises).

${ }^{19}$ See above II.C.2.a).

${ }^{20}$ See Tokeley, above n 18, at 620 .
} 
background, there is not the same force to the arguments for a cooling-off period with regard to telemarketing as with regard to door-to-door sales.

Nevertheless, the psychological advantages of an experienced salesperson over an unprepared customer who is called out of the blue should not be underestimated. Further, enacting one regulation for both uninvited telemarketing and door-to-door selling is appropriate as both methods rely on catching customers off guard and persuading them to conclude a contract on the spot. Both are forced "to make a hurried decision under pressure with no opportunity to view other similar products". ${ }^{21}$ Moreover, in case of telemarketing, consumers are unable to see the product that they are offered to purchase. ${ }^{22}$ It is therefore, in this author's opinion, justified to subject contracts that were made as a result of uninvited telemarketing to the same regulation as door-to-door contracts.

\section{c) What constitutes an invitation for telemarketing?}

Given the above-mentioned consequences, the distinction between "invited" and uninvited telemarketing is of the essence. The law provides some clarity in stating that it does not constitute an invitation if the consumer has "given his or her name or contact details to the supplier other than for the predominant purpose of entering into negotiations relating to the supply of goods or services." ${ }^{23}$ Likewise, it is not considered to be an invitation if the consumer contacted the supplier following an unsuccessful attempt by the supplier to contact the consumer. ${ }^{24}$

These clarifications have been adopted directly from Australian Consumer Law, ${ }^{25}$ however with one noteworthy difference: In Australia, a consumer who has invited a supplier to give a quote for certain goods or services is not regarded to have invited the

${ }^{21}$ At 620.

22 At 620.

${ }^{23}$ Fair Trading Act 1986, s 36K(5)(a)(i).

${ }^{24}$ Fair Trading Act, s 36K(5)(a)(ii).

${ }^{25}$ See Competition and Consumer Act 2010 (Australia), s 69(1A) of sch 2; Ministry of Consumer Affairs, above $n$, at 3 . 
supplier to enter into negotiations. ${ }^{26}$ An identical provision was included in the Consumer Law Reform Bill issued by the Government, stating that a consumer is not deemed to have invited a supplier to enter into negotiations "merely because the consumer has invited the supplier to quote or estimate a price for a supply." 27

It is difficult to see why a customer's request to give a quote should not be sufficient to be regarded as an invitation to enter into negotiations. After all, most negotiations start with a quote. It was therefore, in this author's opinion, appropriate that the Commerce Committee in its report on the Bill recommended restricting this rule to cases where "the supplier has provided an unsolicited quote or estimate". ${ }^{28}$ This wording eventually came to be the law. ${ }^{29}$

\section{d) The Consumer's right to cancel the agreement}

The core mechanism of consumers' protection in uninvited direct sale agreements is provided in s 36M(1) of the Fair Trading Act 1986: The consumer is entitled to cancel any uninvited direct sale agreement by giving notice within five working days after receiving a copy of the agreement compliant with the disclosure requirements set out below. ${ }^{30}$

While the notice may, pursuant to s $36 \mathrm{M}(2)$, be "expressed in any way (including oral or written)", ${ }^{31}$ s $36 \mathrm{M}(3)$ states that the consumer must-unless agreed otherwisecommunicate with the supplier by way of the contact details provided on the front page of the agreement. ${ }^{32}$

The cancellation leads to the agreement being treated as if it had never had effect. ${ }^{33}$ All money paid by the consumer must be immediately repaid. ${ }^{34}$ The consumer is under no

\footnotetext{
${ }^{26}$ Competition and Consumer Act 2010, s 69(2) of sch 2; see also Australian Capital Territory Office of Regulatory Services et al Sales practices: A guide for businesses and legal practicioners (2011) at 11.

${ }^{27}$ Consumer Law Reform Bill 2011 (287-1), cl 18 s 36K(2)(b).

${ }^{28}$ See Consumer Law Reform Bill 2012 (287-2), cl 18 s 36K(2)(b).

${ }^{29}$ See Fair Trading Act, s 36K(5)(b).

${ }^{30}$ Fair Trading Act, s 36M(1).

${ }^{31}$ Fair Trading Act, s 36M(2).

${ }^{32}$ Fair Trading Act, s 36M(3).

${ }^{33}$ Fair Trading Act, s 36O.

${ }^{34}$ Fair Trading Act, s 36P.
} 
obligation to send the goods to the supplier and only has to permit the supplier to collect the goods once the money has been repaid. ${ }^{35}$

\section{e) Disclosure requirements relating to the agreement}

A supplier concluding an uninvited direct sale agreement must comply with a number of requirements stated in s 36L of the Fair Trading Act 1986: The agreement must be in legible writing and be presented clearly and in plain language. ${ }^{36} \mathrm{~A}$ copy of the agreement must be given to the consumer within five working days after it was concluded. ${ }^{37}$

In addition, as mentioned before, the supplier must disclose a certain amount of information to the consumer: On the front page of the agreement, there must be a clear description of the goods or services to be supplied; the supplier's name and contact information; the consumer's name and address; and a summary of the consumer's right to cancel the agreement. ${ }^{38}$ Further, the agreement must contain the total price payable or, if it is not yet ascertainable, the method by which it will be calculated. ${ }^{39}$ Lastly, the agreement must be dated. ${ }^{40}$

The written disclosure requirements regarding the consumer's right to cancel the agreement are surprisingly narrow. They are expressly limited to the cancellation right under s 36M(1), thereby excluding any information on how to express the notice of cancellation. Accordingly, the supplier is under no obligation to provide the potentially crucial information that the consumer must use the contact details provided in the agreement. ${ }^{41}$ A consumer might, for instance, think that it is sufficient simply to refuse acceptance of delivery, which would, however, not constitute a legally effective notice of cancellation.

In contrast, the supplier is obligated to advise the consumer orally before concluding the agreement not only on the right of cancellation but also on how to cancel the

\footnotetext{
${ }^{35}$ Fair Trading Act, s 36Q.

${ }^{36}$ Fair Trading Act, s 36L(1)(a).

${ }^{37}$ Fair Trading Act, s 36L(1)(b).

${ }^{38}$ Fair Trading Act, s 36L(2)(a).

${ }^{39}$ Fair Trading Act, s 36L(2)(b).

${ }^{40}$ Fair Trading Act, s 36L(2)(c).

${ }^{41}$ See above II.C.2.d).
} 
agreement. ${ }^{42}$ Why the latter information is regarded as unnecessary to be provided in writing remains unclear: No explanation was given in the legislative process.

The consequences of a supplier not complying with the requirements set out in $\mathrm{s} 36 \mathrm{~L}$ of the Fair Trading Act 1986 are that the notice period does not start, except if the noncompliance is minor and does not materially prejudice the consumer. ${ }^{43}$

\section{A right of withdrawal in distance selling contracts?}

While New Zealand consumers now have a right to cancel contracts that they concluded as a consequence of telemarketing, it was not deemed necessary to provide consumers with a right of withdrawal from distance selling contracts in general. This paper will next analyse if this was a wise decision.

\section{A. The right of withdrawal pursuant to the Directive on consumer rights}

All distance selling methods have in principle two things in common: First, by definition, ${ }^{44}$ the parties do not meet in person before concluding the contract; second, as an almost inevitable consequence, the buyer cannot inspect the goods he intends to purchase before the performance of the contract.

The latter is, in the opinion of the European Parliament and the Council of the European Union, a problem that justifies granting the consumer a right to cancel the contract: ${ }^{45}$

Since in the case of distance sales, the consumer is not able to see the goods before concluding the contract, he should have a right of withdrawal. For the same reason, the consumer should be allowed to test and inspect the goods he has bought to the extent necessary to establish the nature, characteristics and the functioning of the goods. ... Withdrawal from the contract should terminate the obligation of the contracting parties to perform the contract.

Therefore, in 1997, the European Community enacted the Directive on the protection of consumers in respect of distance contracts, which introduced a right of withdrawal for

\footnotetext{
${ }^{42}$ Fair Trading Act, s 36L(3).

${ }^{43}$ Fair Trading Act, s 36M(1)(b) and 36N(2).

${ }^{44}$ See above II.

${ }^{45}$ Directive 2011/83/EU on consumer rights [2011] OJ L304/64 2011 (European Union), recital 37.
} 
consumers within a period of seven working days. ${ }^{46}$ On June 13, 2014 this Directive was repealed and replaced with the Directive on consumer rights. ${ }^{47}$ Article 9 of said Directive provides consumers with a right to withdraw from a distance contract within 14 calendar days after the delivery of the goods or after the supplier has informed the consumer on the right of withdrawal, whichever comes later. ${ }^{48}$

A number of goods or services are excluded from the right to withdrawal. The first group comprises goods that are not suitable for return, either for hygienic reasons (for instance underwear) or because they are bound to deteriorate rapidly (grocery), because they may already have been fully consumed (magazines, digital content), because they were made to the consumer's specifications or are clearly personalised (tailor-made clothes) or because they are inseparably mixed with other items (heating oil). ${ }^{49}$ The second group consists of those financial goods or services and alcoholic beverages for which the price is dependent on fluctuations in the market. ${ }^{50}$ Further exceptions are contracts concluded at a public auction, ${ }^{51}$ which notably does not include online auctions, ${ }^{52}$ and contracts for certain services related to leisure activities that provide for a specific date or period of performance (hotel reservations, rental cars). ${ }^{53}$

Another important restriction is found in the definition of "distance contract" in art 2(7) of the Directive: This definition requires that the contract was concluded "under an organised distance sales or service-provision scheme", 54 thereby excluding distant sales made ad hoc. Thus, the Directive does not apply to a storeowner who does not operate an online shop but nevertheless accepts a one-time e-mail order.

\footnotetext{
${ }^{46}$ Directive 97/7/EC on the protection of consumers in respect of distance contracts [1997] OJ L144/19 (European Union), art 6.

${ }^{47}$ Directive 2011/83/EU on consumer rights [2011] OJ L304/64.

${ }^{48}$ Directive 2011/83/EU on consumer rights [2011] OJ L304/64, art 9(1)-(2), art 10.

${ }^{49}$ Directive 2011/83/EU on consumer rights [2011] OJ L304/64, art 16(c)-(f), (i), (j), (m).

${ }^{50}$ Directive 2011/83/EU on consumer rights [2011] OJ L304/64, art 16(b), (g).

${ }^{51}$ Directive 2011/83/EU on consumer rights [2011] OJ L304/64, art 16(k).

52 See Directive 2011/83/EU on consumer rights [2011] OJ L304/64, art 2(13).

${ }^{53}$ Directive 2011/83/EU on consumer rights [2011] OJ L304/64, art 16(1).

54 Directive 2011/83/EU on consumer rights [2011] OJ L304/64, art 2(7).
} 


\section{B. Usage of the right of withdrawal}

Unfortunately, not many data on the usage of withdrawal rights in the EU are available. A study conducted by the EU in 2008 based on a consumer survey showed that $19 \%$ of the European citizens engaged in distance contracts had exercised their withdrawal right within 12 months prior to the survey. The percentages per country varied from $1 \%$ in Cyprus up to $29 \%$ in Germany. ${ }^{55}$

A 2011 German study interrogated close to 400 online shops. The survey investigated into the share of withdrawals regarding different product categories. The study showed that, at $28.5 \%$, clothes and shoes are most likely to be returned, whereas between $12 \%$ and $16 \%$ of purchases of any other goods are cancelled. ${ }^{56}$

\section{Analysis of the right of withdrawal from an economic perspective}

In contrast to the European Union, New Zealand did not deem it necessary to provide consumers with a right of withdrawal from distance selling contracts in general. This paper will next analyse if this was a wise decision.

The right of withdrawal has been criticised by scholars using economic approaches. From an economic point of view, withdrawal rights should be granted only if the benefits outweigh the costs. ${ }^{57}$

\section{Costs}

The costs of exercising withdrawal rights comprise transaction costs, legal uncertainty during the cooling-off period and costs that come with delayed or abandoned

\footnotetext{
55 Directorate-General for Communication Consumer Protection in the Internal Market (Special Eurobarometer 298 2008) at 60.

${ }^{56}$ DIHK and Trusted Shops "Auswertung der Umfrage zur Praxis des Widerrufs im Fernabsatz bei Warenlieferungsverträgen auf der Basis von385 Rückantworten" (August 2010) <http://www.dihk. de/ressourcen/downloads/umfrage_widerrufsrecht.pdf $>$ (translation: Analysis of the survey regarding the practice of withdrawal in distance selling contracts based on 385 responses) at 1.

${ }^{57}$ Horst Eidenmueller "Why Withdrawal Rights?" (2011) 7 ERCL 1; SSRN ID 1660535 at 5; Pamaria Rekaiti and Roger Van den Bergh "Cooling-off periods in the Consumer Laws of the EC Member States A Comparative Law and Economics Approach” (2000) 23 JCP 371 at 383.
} 
consumption. ${ }^{58}$ It should be noted that in a competitive market, the costs that are incurred by the suppliers are ultimately borne by all consumers. ${ }^{59}$ Of course, the time and money spent by a consumer for returning a good are costs borne by the particular consumer. The costs for the supplier that are triggered by the withdrawal right however are a position that the supplier will take into account when setting a good's price.

\section{Benefits}

\section{a) Remedy for inefficiencies}

The principal benefit of withdrawal rights is that they provide a remedy for inefficient contracts (contracts where the price paid by the consumer exceeds the benefit to the consumer) ${ }^{60}$ Indirectly, they also provide an incentive for sellers to set product prices corresponding to the product's actual quality. ${ }^{61}$

This benefit is significant if the consumer lacks the opportunity to compare prices of other products. This is the case where the supplier follows a tactic of situational monopolies, which means that the supplier persuades the consumer of the goods being unique or hard to obtain in ordinary stores. ${ }^{62}$ Such tactics are typically used in highpressure sale situations such as telemarketing.

\section{b) Allocation of costs and benefits}

In theory, in a market where all consumers exercise their withdrawal rights applying the same standards and where prices are adjusted accordingly, market prices would reflect these very standards.

According to a 2007 journal article however, "[e]xperience reveals" that $40 \%$ of returns are made by $10 \%$ of customers. ${ }^{63}$ This suggests that on balance a rather small minority of consumers profit strongly from withdrawal rights whereas for the

\footnotetext{
${ }^{58}$ Eidenmueller, above $\mathrm{n} 57$, at 5.

${ }^{59}$ At 5 .

${ }^{60}$ At 5; Rekaiti and Van den Bergh, above n 57, at 374-375.

${ }^{61}$ Rekaiti and Van den Bergh, above n 57, at 381.

${ }^{62}$ At 378-379.

${ }^{63}$ Georg Borges and Bernd Irlenbusch "Fairness Crowded Out by Law: An Experimental Study on Withdrawal Rights" (2007) 163 JITE 84 at 87.
} 
overwhelming majority the costs outweigh the benefits. In other words, withdrawal rights make more individuals worse off than better off.

This finding indicates that from an economic point of view, withdrawal rights are inefficient in terms of the Pareto efficiency. The Pareto efficiency concerns the satisfaction of individual preferences. ${ }^{64}$ A particular situation is Pareto efficient if it is impossible to change it so as to make at least one person better off without making another person worse off. ${ }^{65}$ A Pareto improvement occurs if a change results in the gainers gaining more than the losers lose. ${ }^{66}$

The above finding shows that withdrawal rights make more individuals worse off than better off. This does not necessarily exclude a Pareto improvement, as the gains and the losses need to be compared as a whole. There is no data available as to the amount of gains accrued by those exercising the withdrawal right. Neither are there numbers on the costs incurred by suppliers due to the withdrawal rights. Therefore, it is not possible to definitively judge the Pareto efficiency of withdrawal rights. However, the fact that the number of losers is higher than the number of gainers seems to indicate a likelihood that withdrawal rights are Pareto inefficient. Accordingly, another justification for withdrawal rights must be found.

As far as telemarketing is concerned, the numbers are presumably different. There is no reason to assume that some consumers repeatedly manage to subject themselves to uninvited telemarketing in order to systematically exercise their withdrawal rights. The risk of consumers systematically using their withdrawal rights is minimised by protecting only those who did not initiate negotiations.

\section{c) Preventing the market from collapsing}

The danger of distance selling to consumers lies in the information asymmetries: The characteristics of goods sold in distance contracts are only ascertainable after the performance of the contract. ${ }^{67}$ Consumers therefore do not know how much they will

\footnotetext{
${ }^{64}$ Robert Cooter Law \& Economics (6th ed, Addison-Wesley, Boston, 2012) at 14.

${ }^{65}$ At 14.

${ }^{66}$ At 42 .

${ }^{67}$ Eidenmueller, above n 57, at 7.
} 
value the goods that they could receive. Since they do not know the goods' potential benefit, they are uncertain as to the cost they should incur for the transaction. ${ }^{68}$

When consumers are not able to determine a good's value, they are likely to assume the average value thereof and are accordingly unwilling to pay more than the average price. ${ }^{69}$ This leads to traders being unable to sell high quality goods for an appropriate price, the average quality of goods therefore deteriorating, and ultimately the whole market for these goods collapsing. ${ }^{70}$ This phenomenon is named "market for lemons" after a Nobel Prize winning paper published in 1970 by George Akerlof. ${ }^{71}$

Withdrawal rights are an effective remedy against such a course of events because they should, by minimising transaction risks, encourage consumers to purchase supposedly high quality goods for higher prices. ${ }^{72}$ On the other hand, an argument can be made that traders have other options to reduce information asymmetries, for instance by issuing guarantees ${ }^{73}$ or by voluntarily offering withdrawal rights where they are not mandatory. ${ }^{74}$ These are what Akerlof calls "counteracting institutions" because they counteract the effects of quality uncertainty by indicating a certain quality. Other examples given by Akerlof include brand names, chains, licensing or certifications. ${ }^{75}$ From today's perspective, one could add media articles and customer reviews or ratings. All those provide consumers with information on the quality of a good or service that consumers otherwise could not obtain.

Whether the benefits of withdrawal rights outweigh the related costs is difficult to assess. The situation in New Zealand, Australia and the United States however reveals that, even absent mandatory withdrawal rights, distance selling markets have anything but

\footnotetext{
${ }^{68}$ Joasia Luzak To Withdraw or Not to Withdraw? Evaluation of the Mandatory Right of Withdrawal in Consumer Distance Selling Contracts Taking into Account Its Behavioural Effects on Consumers (SSRN ID 2243645 2013) at 5.

${ }^{69}$ George A Akerlof “The Market for 'Lemons': Quality Uncertainty and the Market Mechanism” (1970) 84 QJE 488 at 489; Luzak, above n 68, at 5.

${ }^{70}$ Akerlof, above n 69, at 489-490; Luzak, above n 68, at 5; Eidenmueller, above n 57, at 7.

${ }^{71}$ Akerlof, above n 69; see Luzak, above n 68, at 5.

${ }^{72}$ Luzak, above n 68, at 6; Eidenmueller, above n 57, at 8.

${ }^{73}$ Akerlof, above n 69, at 499; Eidenmueller, above n 57, at 8.

${ }^{74}$ Eidenmueller, above n 57, at 8.

${ }^{75}$ Akerlof, above n 69, at 499-500.
} 
collapsed. Experiences made in these markets suggest that the aforementioned counteracting institutions effectively counterbalance the information asymmetries. ${ }^{76}$ This leads to the conclusion that distance selling markets are not an example of a market for lemons.

\section{d) Withdrawal rights and "showrooming"}

Withdrawal rights might have the effect of re-allocating the costs of "showrooming". This term was coined in 2010 in the United States by retail analysts and media outlets to describe the phenomenon of consumers using a retailer as a showroom to view products in-person (and possibly even seek advice) before buying them from an online retailer. ${ }^{77}$

A 2013 study conducted in the United States, Canada and the United Kingdom asked consumers, who were currently using their mobile computing devices (mobile-assisted shoppers) as part of their shopping experience in retail stores, about their showrooming habits. ${ }^{78}$ The study revealed that $70 \%$ of the respondents reported having showroomed in the previous year. The authors compared this finding to the results of other studies, which had demonstrated showrooming behaviour in up to $60 \%$ of consumers, and explained the higher rate of showroomers in this study with mobile-assisted shoppers being more digitally sophisticated than the average shopper. ${ }^{79}$ In terms of product categories showroomers most frequently research electronics and appliances, with books and music on second place. ${ }^{80}$

According to the study, 6\% of consumers reported having "showroomed" in a premeditated fashion, which the study defines as planning to purchase the product online and merely visiting the store to preview it in-person. ${ }^{81}$ Another $13 \%$ had similarly done pre-planned showrooming, but they were still ready to buy in store, weighing a variety of

\footnotetext{
${ }_{76}$ Rekaiti and Van den Bergh, above n 57, at 379-380.

${ }^{77}$ Matthew Quint, David Rogers and Rick Ferguson "Showrooming and the Rise of the Mobile-Assisted Shopper" (September 2013) <https://www4.gsb.columbia.edu/filemgr?file_id=7313935> at 3.

78 At 3.

79 At 11 .

${ }^{80}$ At $10-11$.

${ }^{81}$ At 15.
} 
factors in addition to price. ${ }^{82}$ A further group of $19 \%$ had showroomed without planning ahead and indicated that they would never purchase a product in a retail store when they knew they could buy it for an equal or lower price online. ${ }^{83}$

Both showrooming and withdrawal rights serve the same purpose: to let the customer inspect the goods. Since consumers cannot do that when purchasing goods online, they might be inclined to go view the product in a store, with no intention of buying it there. This is what retailers in the United States complained about: their stores being used as showrooms for online shops. ${ }^{84}$ While the costs of showrooming (investments in store facilities, personnel and displayed products) are borne by the retailers, the profits are made by the online stores where the products are finally purchased. Therefore, from an online store's perspective the costs of showrooming can be regarded as external costs. Online stores can save the costs of presenting their stock in showrooms because their customers are willing to go to bricks-and-mortar stores for that purpose.

Against this background, withdrawal rights can be seen as a mechanism to diminish the external costs of showrooming and have the online stores internalise them. For once, introducing withdrawal rights could reduce the frequency of showrooming as they provide consumers with an opportunity to inspect the goods at home before deciding on whether to cancel the purchase. In addition, withdrawal rights impose on online stores the costs that are associated with customers inspecting the products. It could therefore be argued that the costs caused by withdrawal rights are counterbalancing the costs associated with showrooming.

However, there is another phenomenon to be considered, which is referred to as "reverse showrooming" or "webrooming", meaning consumers doing research on a product online and then buying it in store. ${ }^{85}$ Data from the United States suggest that this is actually more common than showrooming, and most "webroomers" start their research

\footnotetext{
${ }^{82}$ At 17.

${ }^{83}$ At 18 .

${ }^{84}$ At 3.

${ }^{85}$ Linh N Lingenfelter and Andrew J Ferren "Reverse Showrooming: A Look at the Other Side" (24 September 2014) Retail Law Advisor <www.retaillawadvisor.com/2014/09/24/reverse-showrooming-alook-at-the-other-side>.
} 
at online shops. ${ }^{86}$ It thus appears that, similar to online shops using bricks-and-mortar stores as their showrooms, bricks-and-mortar stores profit from online shops gathering and providing information on their products. The relationship between these two kinds of suppliers seems more complex and symbiotic than anticipated.

Taking into account the bricks-and-mortar stores' possibilities to profit from online shops, there is no clear need for withdrawal rights to shift showrooming costs from bricks-and-mortar stores to online shops.

\section{Analysis of the right of withdrawal from a behavioural psychology perspective}

From a behavioural psychology perspective, the assumption that withdrawal rights help consumers in concluding more efficient contracts is questionable: First, because not all grounds for withdrawal rights turn out to be valid; second, because some psychological phenomena might prevent consumers from exercising their rights; and third, because withdrawal rights might end up having side effects that may be detrimental to the goal they seek to achieve.

\section{Grounds for withdrawal rights}

There are three grounds that are put forward to justify withdrawal rights. This paper will now briefly evaluate these grounds.

\section{a) Cooling-off}

The time span in which a consumer may withdraw from a contract is referred to as a "cooling-off period". As the term suggests it is designed to allow the consumer to calm down and think again. ${ }^{87}$

However, there is no empirical evidence that consumers concluding distance selling contracts are more prone to be led by their emotions than consumers buying goods in a store. ${ }^{88}$ Thus, no need for a "cooling-off" has been established.

\footnotetext{
${ }^{86}$ Lingenfelter and Ferren, above $\mathrm{n} 85$.

${ }^{87}$ Luzak, above n 68, at 11.

${ }^{88}$ At 12.
} 
The exception in this regard is telemarketing. As noted above, telemarketing is the direct selling form of distance selling. ${ }^{89}$ Telemarketers often use high-pressure marketing tactics that make consumers prone to irrational decision-making. ${ }^{90}$ Accordingly, it is submitted that granting consumers who have concluded a contract as a consequence of telemarketing a cooling-off period is a valid motive for withdrawal rights.

\section{b) Information bias}

It is not disputed that consumers typically have significantly less information on the goods than the trader. ${ }^{91}$ The cooling-off period will allow them to gather information on the purchased good in use.

Some legal scholars have argued that granting withdrawal rights would destroy all incentives for consumers to gather sufficient information in advance and assess the value of the good..$^{92}$ However, this argument is in this author's view not persuasive because by exercising withdrawal rights the consumers will still incur some costs (at least the costs of re-packaging and dispatching the goods). This should provide sufficient incentive for not deliberately refraining from collecting enough information.

In this author's opinion, reducing information bias is a valid goal to be achieved by introducing withdrawal rights.

\section{c) Trust and confidence}

Distance selling requires consumers' trust and confidence in the security, privacy and reliability of the transactions. ${ }^{93}$ A lack of trust could prevent consumers from using certain distance selling methods, in particular online shopping. ${ }^{94}$

A 2011 study conducted for the Directorate General for Health and Consumers of the European Commission revealed as the greatest concern of European consumers about

\footnotetext{
${ }^{89}$ See above II.C.1.

${ }^{90}$ Rekaiti and Van den Bergh, above n 57, at 376.

${ }^{91}$ See Luzak, above $\mathrm{n} 68$, at 13.

${ }^{92}$ See Horst Eidenmueller, above n 57, at 13; Luzak, above n 68, at 28.

${ }^{93}$ Luzak, above n 68, at 15.

${ }^{94}$ At 15; Gurvinder S Shergill and Zhaobin Chen "Web-Based Shopping: Consumers' Attitudes Towards Online Shopping in New Zealand" (2005) 6 Journal of Electronic Commerce Research 79 at 81.
} 
buying goods online (mentioned by $31 \%$ of the respondents) potential difficulties when returning products and claiming reimbursement of the price. ${ }^{95}$ The second and third most mentioned concerns were that wrong or damaged products would be delivered (29\%) and that replacement or repair of a faulty product would not be easy $(26 \%) .{ }^{96}$ Further, consumers are concerned about non-delivery $(21 \%)$, misuse of personal data $(21 \%)$, theft of payment card details (20\%) or long delivery times $(18 \%){ }^{97}$

When asked about cross-border transactions, long delivery times became the chief concern of consumers (mentioned by $35 \%$ of the respondents), followed by difficulties in getting reimbursed (34\%) and having faulty products replaced or repaired (29\%) and nondelivery (27\%). ${ }^{98}$ Delivery of wrong or damaged goods (23\%), theft of payment card details $(21 \%)$ and misuse of personal data (19\%) seem to be less pressing issues. ${ }^{99}$

None of these concerns are directly addressed by establishing withdrawal rights. However, consumers could choose to resolve the issues of receiving wrong or damaged products by exercising their withdrawal rights rather than their rights designed to remedy such breaches of contract. Additionally, one of consumers' main concerns turns out to be whether they are able to effectively exercise their withdrawal rights, which might suggest that those are perceived as a key element of distance selling.

Unfortunately, no study is available as to the consumers' concerns before withdrawal rights were introduced. Therefore, the effect of the regulation cannot be reliably assessed in this paper. It seems though that, on balance, while withdrawal rights make it easier for consumers to deal with receiving wrong or faulty goods, they are not a particularly suited mechanism to restore consumers' trust and confidence in distance selling.

The same appears to hold true for New Zealand. While no comparable data on New Zealand is available, a 2005 study seems to suggest that the reliability of online suppliers

\footnotetext{
${ }_{95}$ Frank Alleweldt and Sendra Kara "Consumer market study on the functioning of e-commerce and Internet marketing and selling techniques in the retail of goods" (9 September 2011) $<$ http://ec.europa.eu/consumers/archive/consumer_research/market_studies/docs/study_ecommerce_goods_ en.pdf $>$ at 129 .

${ }^{96}$ At 129.

${ }^{97}$ At 129.

${ }^{98}$ At 132.

${ }^{99}$ At 132.
} 
is less of an issue for New Zealand consumers. ${ }^{100}$ Even respondents who only occasionally order goods online indicated that they were satisfied with the delivery process. They however expressed concerns about the safety of their transactions and the protection of their privacy. ${ }^{101}$ These results seem to confirm that a lack of trust in online suppliers by New Zealand consumers is not caused by the fear of receiving a product that does not meet their expectations.

\section{Reasons potentially hindering the exercise of withdrawal rights}

A number of psychological phenomena might prevent consumers from exercising their rights of withdrawal. These are set out below.

\section{a) Endowment effect}

Studies suggest that consumers attach a higher value to the goods they own than to those they do not own. ${ }^{102}$ Therefore, consumers are likely to overestimate a good's value once they have received it. Since the consumers' attachment to a good is likely to increase with every day it is in their possession, they are increasingly prone to keep the goods the longer they wait until deciding on whether to exercise their withdrawal right. ${ }^{103}$

\section{b) Aversion to loss}

It is well established that people experience losses heavier than they perceive gains. ${ }^{104}$ It is likely that consumers perceive withdrawing from a contract and thus having to give back the good as a loss, both due to the endowment effect and due to actual costs associated with returning the goods. ${ }^{105}$

\section{c) Status quo bias}

Consumers typically fear the negative consequences of their actions more than those of their omissions. This could be caused by consumers perceiving activity as more abnormal

\footnotetext{
100 See Shergill and Chen, above n 94, at 90.

101 See at 90.

${ }^{102}$ Luzak, above n 68, at 19.

103 At 19-20.

104 See at 18.

105 See at 18-19.
} 
than inactivity or by consumers feeling personally responsible for their own actions, whereas the result of inactivity may seem more like an act of god. ${ }^{106}$ Therefore, consumers tend to maintain the current state of affairs, which is referred to as the status quo bias. ${ }^{107}$

\section{d) Cognitive dissonances}

Cognitive dissonance is the discomfort experienced by people who are confronted with new information that is inconsistent with their pre-existing beliefs. In order to avoid said discomfort, people have been shown to look for or interpret information in a way that confirms their beliefs (also known as confirmation bias). Accordingly, consumers might diminish or disregard findings that suggest the good purchased being of a lower than expected quality. ${ }^{108}$

\section{e) Procrastination}

Procrastination has been defined as voluntarily delaying an intended course of action despite expecting to be worse off for the delay. ${ }^{109}$ It is a phenomenon experienced by many consumers with regard to onerous tasks. ${ }^{110}$ Specifically, studies have showed that an action is likelier to be postponed when a longer time frame is allowed for the action to take place. ${ }^{111}$ Therefore, perhaps counter-intuitively, if people have a longer period and thus more opportunities for performing a task, they are less likely to do it. ${ }^{112}$

This suggests that a longer cooling-off period might not be as beneficial to consumers as it is generally thought to be. ${ }^{113}$

\footnotetext{
${ }^{106}$ At 20-21.

${ }^{107}$ At 22.

${ }^{108}$ At 23.

109 Wikipedia, the free encyclopedia (2014) Procrastination <http://en.wikipedia.org/w/index.php?title= Procrastination\&oldid $=621677289>$.

${ }^{110}$ Luzak, above n 68, at 24 .

111 See Hanneke Arendina Luth "Behavioural Economics in Consumer Policy" (Erasmus Universiteit, 2010) at 54.

${ }^{112}$ At 54 .

${ }^{113}$ Luzak, above n 68, at 25 .
} 


\section{A possible side effect of withdrawal rights?}

A more concerning phenomenon, which could actually render withdrawal rights detrimental to consumer welfare, is referred to as "overchoice" or "paradox of choice".

Studies show that, when faced with too many options, consumers have trouble making optimal choices, and thus can become indecisive and unhappy. ${ }^{114}$ Consumers who are constantly facing more choice are likely to be dissatisfied with the goods they already have and to feel compelled to continue searching for better goods. ${ }^{115}$ This could mean that giving consumers an additional choice by granting them the option to withdraw from the contract is not to the benefit of consumers. ${ }^{116}$

However, a 2005 study suggests that the opportunity to exchange the chosen product can reduce the potential for a consumer's regret with a choice and thus the effect of overchoice. ${ }^{117}$ This might indicate that withdrawal rights are not perceived as a further option contributing to an overload of choice but as a remedy for wrong choices. It should be noted however that in the study the choice on whether to exchange the product was to be made by a third person. ${ }^{118}$ Thus, it did not add to the total number of options from which the subjects had to choose.

\section{Summary}

An examination of the psychological phenomena surrounding the exercise of withdrawal rights in distance selling contracts reveals that, with the exception of telemarketing (where arguments for a cooling-off period are persuasive due to the high pressure sales techniques often employed by callers) only the argument of the information asymmetries between traders and consumers is confirmed by empirical evidence.

\footnotetext{
${ }^{114}$ Robert B Settle and Linda L Golden "Consumer Perceptions: Overchoice in the Market Place" (1974) 1 Advances in Consumer Research 29 at 36-37; Luzak, above n 68, at 26-27.

${ }^{115}$ Luzak, above $\mathrm{n} 68$, at 26.

${ }^{116}$ Christian Twigg-Flesner and Reiner Schulze "Protecting rational choice: information and the right of withdrawal" in Geraint G Howells, Ian M Ramsay and Thomas Wilhelmsson (eds) Handbook of Research on International Consumer Law (Edward Elgar Publishing, Cheltenham (UK), 2010) 130 at 130; Luzak, above $\mathrm{n} 68$, at 27.

117 John T Gourville and Dilip Soman "Overchoice and Assortment Type: When and Why Variety Backfires" (2005) 24 Marketing Science 382 at 393.

118 At 392.
} 
On the other hand, the psychological phenomena operating against consumers exercising withdrawal rights, though not to be underestimated will presumably not prejudicially affect consumer welfare as they merely indicate that consumers are not likely to make entirely reasonable use of their rights. As far as the problem of overchoice is concerned, empirical evidence seems to indicate that it will be reduced by withdrawal rights rather than enhanced.

On balance, while studies indicate that consumers will rather benefit from withdrawal rights, no strong case can be made from a behavioural psychology perspective.

\section{E. Analysis of the right of withdrawal from an ethical perspective}

The question whether mandatory rights of withdrawal should be introduced for distance selling contracts should not be answered solely based on economical and behavioural psychological considerations. Ethical arguments must play a part in the discussion as well. Thus, this paper will investigate two ethical questions: First, if a mandatory right of withdrawal is fair to suppliers and second, if it is fair to consumers.

\section{Fairness from the suppliers' perspective}

\section{a) A general right of withdrawal in distance selling contracts}

From the suppliers' perspective, mandatory withdrawal rights are a massive interference with contractual freedom, and a one-sided one: The right to withdraw is granted to consumers only, not to both parties to the agreement.

In addition, a withdrawal right in distance selling contracts raises the issue that consumers who purchase goods in store do not have a right to cancel the contract. Bricksand-mortar stores and online shops are thus treated differently. The reason given by the European Parliament and the Council of the European Union is that in distance selling contracts "the consumer is not able to see the goods before concluding the contract" and should therefore be allowed to test and inspect the goods. ${ }^{119}$ However, while consumers in distance selling contracts undeniably lack the opportunity to inspect the good they are about to purchase, the same is true for many in-store purchases. Typically, products are

${ }^{119}$ See above III.A. 
pre-packaged. While some stores provide display items to let customers see and inspect them, others do not and it is uncertain if those would allow customers to unpack and inspect products, let alone test them. In any event, they are not legally obligated to do so. Therefore, no compelling argument can be made from the consumers' inability to see the product before concluding the contract.

The only remaining possible justification for withdrawal rights is to counteract the phenomenon known as showrooming. However, as shown above, the relationship between bricks-and-mortar stores and online shops is not a one-way street in the sense that online shops take the profits and leave the bricks-and-mortar stores with the costs. Many consumers use online shops to get informed about certain products and then buy them elsewhere. In this regard, bricks-and-mortar stores are freeriding at the expense of online shops. Against this background, it does not seem appropriate to simply pick one free-riding phenomenon in the relationship between bricks-and-mortar stores and online shops and attempt to remedy it.

\section{b) A right of withdrawal in telemarketing}

Turning to telemarketing however, we find more compelling reasons for mandatory withdrawal rights. Telemarketing is a sales technique that typically puts consumers in a pressure type situation and prompts them to make a hurried decision. Some telemarketers take further advantage of their situational monopoly by selling their products at prices that consumers, were they able to compare with competitor's prices, would not agree to pay. Mandatory withdrawal rights address both these issues by providing consumers with a cooling-off period that enables them to rethink their decision free of pressure.

Not burdening bricks-and-mortar stores and online shops with the same consumers' rights is justified even though some salespersons in retail stores are able to build a similar type of pressure on consumers. What makes the difference is that consumers can do research before entering a store and are then free to decide if they want to enter a store and potentially be subjected to the personnel's sales techniques. Consumers who receive a cold call however cannot make the same decision free of pressure. This is why consumers are granted withdrawal rights only in case of uninvited telemarketing where 
they are caught off guard. When consumers invite suppliers to enter into negotiations, then it is their responsibility to make sure they are prepared.

\section{Fairness from the consumers' perspective}

\section{a) A general right of withdrawal in distance selling contracts}

The second question is whether mandatory withdrawal rights are fair to consumers. It is a valid question because consumers do not get to choose if they want these rights-instead, the rights are imposed on them. They are an example of hard paternalism. In order to answer the question, the advantages and disadvantages of withdrawal rights from the consumers' perspective must be balanced. The consumers' advantage is that they have a remedy for inefficient contracts. The disadvantage lies in the costs associated with the exercise of withdrawal rights, which the suppliers will put in their price calculation.

In this regard, it has been shown above that the average consumer is not an avid user of the withdrawal right. Rather, it is a small minority of consumers that accounts for a big part of the contract cancellations. Therefore, while the benefits of the withdrawal rights are realised by a minority of consumers only, the costs (as reflected in higher prices) are borne by all consumers. Accordingly, withdrawal rights leave more consumers worse off than better off, which is an astonishing result for a paternalistic legal remedy intended to increase consumer welfare.

Experience in unregulated markets shows that, following the example set by the inventor of distance selling who promised "satisfaction or your money back" 120 , many distance sellers grant their customers the right to return their goods. ${ }^{121}$ Some suppliers however do not, which allows them to offer their customers lower prices or other extras. $^{122}$ This leaves consumers with the choice either to opt for security through a right to withdraw from the contract should they not like the good or to go for lower prices or

\footnotetext{
120 “Aaron Montgomery Ward (1843-1913)", above n 1.

${ }^{121}$ See for instance The Warehouse on <http://www.thewarehouse.co.nz/red/content/homepage/customerservices/returns $>$ or, with some limitations, Noel Leeming < https://www.noelleeming.co.nz/shop/customerservice/keyword-returns\%20and\%20exchanges.html> and Fishpond on <www.fishpond.co.nz/ helpdesk.php?question_id=126>.

${ }^{122}$ See for instance Dick Smith on <www.dicksmith.co.nz/shopping-with-us/our-returns-policy-nz>.
} 
whatever extra they might prefer. This freedom of choice is, in this author's opinion, preferable to mandatory withdrawal rights.

\section{b) A right of withdrawal in telemarketing}

The relevant circumstances for contracts that are concluded as a consequence of telemarketing are different.

In terms of the costs associated with the withdrawal there is no denying that these will add to the overall costs to be borne by the consumers. However, at the same time, it can be expected that prices that are too high compared to the product's actual quality will be lowered by traders in order not to incentivise consumers to withdraw.

Given that the right of withdrawal is granted only to consumers who were called without invitation there is hardly a potential for abuse of the right. Therefore, it can be assumed that costs and benefits are distributed more fairly. Further, rights of withdrawal are targeted at helping consumers who were caught in a momentary weakness. This goal would, in this author's opinion, justify a slight decrease of the average consumer's welfare.

\section{Conclusions}

An economical analysis of withdrawal rights in distance selling contracts reveals that there is no conclusive evidence that such rights are Pareto efficient. Rather, the available data indicates that they leave more consumers worse off than better off.

Further, experience in many distance selling markets, especially e-commerce markets, shows that the informational asymmetries between traders and consumers are effectively counteracted by several institutions, which renders withdrawal rights unnecessary to address these deficiencies.

Lastly, when it comes to showrooming, the effects caused by this phenomenon must not be assessed in isolation as they are part of a larger, more complex and potentially symbiotic relationship between bricks-and-mortar stores and online shops, in which the former may also profit from the latter. 
As far as telemarketing is concerned, the informational asymmetries are often exploited by suppliers employing a tactic of situational monopolies. Endowing consumers with a remedy is therefore an appropriate measure. In addition, there is no reason to assume that some consumers repeatedly manage to subject themselves to uninvited telemarketing in order to systematically exercise their withdrawal rights. Therefore, it can be assumed that costs and benefits are distributed more fairly.

An examination of the psychological arguments brought forward in favour of withdrawal rights in distance selling contracts (cooling-off; information bias; lack of trust and confidence) reveals that only one of them is based on empirical evidence: the argument of the information asymmetries between traders and consumers. In terms of telemarketing, however, arguments for a cooling-off period are persuasive given the high pressure sales techniques often employed by callers.

On the other hand, the psychological phenomena operating against consumers exercising withdrawal rights will presumably not prejudicially affect consumer welfare. This holds true both for distance selling contracts in general and telemarketing contracts. While the psychological effects should not be underestimated, they merely indicate that consumers are not likely to make entirely reasonable use of their rights rather than that withdrawal rights are not beneficial to consumers. As far as the problem of overchoice is concerned, empirical evidence seems to indicate that it will be reduced by withdrawal rights rather than enhanced. On balance, while studies indicate that consumers will rather benefit from withdrawal rights, no strong case can be made from a behavioural psychology perspective.

In summary, both the economical and psychological evidence indicate that a right of withdrawal in distance selling contracts is not beneficial to overall consumer welfare. It is therefore submitted that consumers profit more from being able to choose between suppliers that offer a generous policy in terms of returning products and suppliers that focus on lower costs and prices.

In addition, from a supplier's point of view it is difficult to understand why online shops should be forced to let consumers inspect and test the goods whereas the same obligation is not imposed on bricks-and-mortar stores. 
Against this background, neither the economical and psychological evidence nor ethical considerations justify imposing on consumers and online shops a mandatory right of withdrawal. Instead, rights of withdrawal should be restricted to situations where evidence shows an actual need, which is in this author's opinion the case where consumers are induced to conclude a contract through uninvited telemarketing. From an economical point of view, the efficiency of rights of withdrawal is better in these situations, and psychologically the benefit of a cooling-off period is plausible.

Therefore, the stance taken by the New Zealand legislator to grant consumers a withdrawal right in cases of uninvited telemarketing only is deemed appropriate. 


\section{BIBLIOGRAPHY}

PRIMARY SOURCES

\section{A Cases}

Commerce Commission v Telecom Mobile Ltd NZCA 218, [2006] 1 NZLR 190 (NZCA).

\section{B Legislation}

1 New Zealand

Fair Trading Act 1986.

\section{Australia}

Competition and Consumer Act 2010.

\section{European Union}

Directive 2011/83/EU on consumer rights [2011] OJ L304/64 2011.

Directive $97 / 7 / \mathrm{EC}$ on the protection of consumers in respect of distance contracts [1997] OJ L144/19.

\section{SECONDARY SOURCES}

\section{A Books and Chapters in Books}

Cooter, Robert Law \& Economics (6th ed, Addison-Wesley, Boston, 2012).

Twigg-Flesner, Christian and Schulze, Reiner "Protecting rational choice: information and the right of withdrawal" in Geraint G Howells, Ian M Ramsay and Thomas Wilhelmsson (eds) Handbook of Research on International Consumer Law (Edward Elgar Publishing, Cheltenham (UK), 2010) 130.

\section{B Journal Articles}

Akerlof, George A “The Market for 'Lemons': Quality Uncertainty and the Market Mechanism" (1970) 84 QJE 488.

Borges, Georg and Irlenbusch, Bernd "Fairness Crowded Out by Law: An Experimental Study on Withdrawal Rights" (2007) 163 JITE 84.

Eidenmueller, Horst “Why Withdrawal Rights?” (2011) 7 ERCL 1; SSRN ID 1660535.

Gourville, John T and Soman, Dilip "Overchoice and Assortment Type: When and Why Variety Backfires” (2005) 24 Marketing Science 382.

Rekaiti, Pamaria and Bergh, Roger Van den "Cooling-off periods in the Consumer Laws of the EC Member States. A Comparative Law and Economics Approach" (2000) 23 JCP 371. 
Settle, Robert B and Golden, Linda L "Consumer Perceptions: Overchoice in the Market Place" (1974) 1 Advances in Consumer Research 29.

Shergill, Gurvinder S and Chen, Zhaobin "Web-Based Shopping: Consumers' Attitudes Towards Online Shopping in New Zealand" (2005) 6 Journal of Electronic Commerce Research 79.

Tokeley, Kate "Telemarketing and the Door to Door Sales Act 1967" (2006) 37 VUWLR 609.

\section{Parliamentary and Government Materials}

Consumer Law Reform Bill 2011 (287-1).

Consumer Law Reform Bill 2012 (287-2).

\section{Reports}

Directorate-General for Communication Consumer Protection in the Internal Market (Special Eurobarometer 298 2008).

Alleweldt, Frank and Kara, Sendra "Consumer market study on the functioning of ecommerce and Internet marketing and selling techniques in the retail of goods" (9 September

$<$ http://ec.europa.eu/consumers/archive/consumer_research/market_studies/docs/study_e commerce_goods_en.pdf $>$.

Ministry of Consumer Affairs Consumer Law Reform Additional Paper: Regulation of Uninvited Direct Selling (2010).

Australian Capital Territory Office of Regulatory Services et al Sales practices: A guide for businesses and legal practicioners (2011).

\section{Dissertations}

Luzak, Joasia To Withdraw or Not to Withdraw? Evaluation of the Mandatory Right of Withdrawal in Consumer Distance Selling Contracts Taking into Account Its Behavioural Effects on Consumers (SSRN ID 2243645 2013).

Luth, Hanneke Arendina "Behavioural Economics in Consumer Policy" (Erasmus Universiteit, 2010).

\section{E Internet Resources}

DIHK and Trusted Shops "Auswertung der Umfrage zur Praxis des Widerrufs im Fernabsatz bei Warenlieferungsverträgen auf der Basis von385 Rückantworten” (August 2010) <http://www.dihk.de/ressourcen/downloads/umfrage_widerrufsrecht.pdf> (translation: Analysis of the survey regarding the practice of withdrawal in distance selling contracts based on 385 responses). 
Lingenfelter, Linh N and Ferren, Andrew J "Reverse Showrooming: A Look at the Other Side" (24 September 2014) Retail Law Advisor <www. retaillawadvisor.com/2014/09/24/reverse-showrooming-a-look-at-the-other-side>.

Quint, Matthew, Rogers, David and Ferguson, Rick "Showrooming and the Rise of the Mobile-Assisted Shopper" (September 2013) <https://www4.gsb.columbia.edu/ filemgr?file_id=7313935>.

Wikipedia, the free encyclopedia (2014) Aaron Montgomery Ward <http://en. wikipedia.org/w/index.php?title=Aaron_Montgomery_Ward\&oldid=613392551 $>$.

Wikipedia, the free encyclopedia (2014) Procrastination <http://en.wikipedia.org/ w/index.php?title=Procrastination\&oldid $=621677289>$.

Wikipedia, the free encyclopedia (2014) Pareto efficiency <http://en.wikipedia.org/ w/index.php?title=Pareto_efficiency\&oldid $=623845898>$.

Wikipedia, the free encyclopedia (2014) Telemarketing <http://en.wikipedia.org/ w/index.php?title $=$ Telemarketing\&oldid $=617088640>$.

“Aaron Montgomery Ward (1843-1913)" Forbes.com <www.forbes.com/2005/07/08/ montgomery-ward-sears-debt-cx_0708ward.html>. 